\title{
Aislamiento de microRNAs a partir de células clorofílicas de Bouteloua gracilis y su caracterización in silico
}

\author{
Isolation of microRNAs from Bouteloua gracilis \\ chlorophyllous cells and their in silico characterization
}

\author{
Perla Lucía Ordóñez-Baqueraa, Everardo González-Rodrígueza, Gerardo Armando \\ Aguado-Santacruzb, Quintín Rascón-Cruzc ${ }^{\mathrm{c}}$ Eduviges Burrola-Barrazaa
}

\begin{abstract}
RESUMEN
Bouteloua gracilis es un pasto nativo del norte de México, que es utilizado como fuente de forraje para el ganado por su alto contenido nutritivo; tiene elevada tolerancia al estrés osmótico que le permite vivir en climas secos; sin embargo, los mecanismos moleculares que le confieren esta tolerancia aún no se han reportado. Existe una clase de RNAs pequeños (sRNAs) Ilamados microRNAs (miRNAs), que se unen por complementariedad a RNAs mensajeros blanco, etiquetándolos para su degradación o supresión de la traducción. En este trabajo se reporta el aislamiento de SRNAs de B. gracilis, a través de la clonación de concatámeros y su secuenciación. El análisis in silico de la secuencias, permitió la identificación de miRNAs conservados en B. gracilis y reportados en Populus trichocarpa, Brachypodium distachyon, Oryza sativa, Sorghum bicolor, Zea mays, Malus domestica y Linum usitatissimum. Además, se predijo la estructura secundaria de los precursores de dos miRNAs (pre-miRNAs), usando como referencia los genomas de Glycine max, Zea mays, Sorghum bicolor y Oryza sativa. Finalmente, se identificaron seis mRNAs blanco para uno de ellos. La identificación de miRNAs en Bouteloua gracilis, ayudará a comprender como estas moléculas regulan la expresión genética en esta especie, y sus relaciones con los mecanismos de respuesta a estrés ambiental.
\end{abstract}

PALABRAS CLAVE: Navajita azul, miRnAs, Regulación genética, Análisis bioinformático.

\begin{abstract}
Bouteloua gracilis is a grass native to Mexico, it is used as forage source for livestock because of its high nutritional value. It has high tolerance to osmotic stress and therefore can live in arid zones; however, regulation mechanisms in gene expression that confer these characteristics have not been reported. There is a class of small RNAs (sRNAs) called microRNAs (miRNAs), which regulate gene expression. They are complementary and act by binding to messenger RNAs (mRNAs to inhibit translation or by degrading them. In this work, the isolation of sRNAs from B. gracilis through cloning and sequencing of concatemers is reported. In silico analysis of the sequences obtained allowed to identify conserved sequences in Populus trichocarpa, Brachypodium distachyon, Oryza sativa, Sorghum bicolor, Zea mays, Malus domestica, and Linum usitatissimum. Furthermore, the secondary structure of the miRNA precursor (premiRNA) was predicted from two sequences isolated from In silico analysis using Glycine max, Zea mays, Sorghum bicolor, and Oryza sativa as reference genomes. Finally, six target mRNAs were identified for one of the miRNAs obtained. Identification of miRNAs in Bouteloua gracilis will help to understand how these molecules regulate gene expression and in the future will allow for the study at molecular level, providing insight on how this grass responds to environmental stress.
\end{abstract}

KEY WORDS: Blue gramma, miRNAs, Genetic regulation, Bioinformatics analysis.

Recibido el 20 de mayo de 2015. Aceptado el 19 de septiembre de 2015.

a Facultad de Zootecnia y Ecología, Universidad Autónoma de Chihuahua. Periférico R. Almada Km. 1 C.P. 31453, Chihuahua, Chihuahua, México. Tel (614) 4340303. evegonzal@uach.mx. Correspondencia al segundo autor.

b Programa de Posgrado, Instituto Tecnológico de Roque. Celaya, Guanajuato, México.

c Facultad de Ciencias Químicas, Universidad Autónoma de Chihuahua. Chihuahua, México. 


\section{INTRODUCCIÓN}

Los miRNAs son secuencias de RNA de cadena sencilla, de 18 a 25 nucleótidos de longitud; en plantas, su biogénesis inicia cuando los genes MIRNAS son transcritos por la RNA polimerasa II, generando transcritos primarios con longitudes de 200 a 300 nucleótidos denominados como pri-miRNAs, que son procesados a una estructura única de talloburbuja por la acción de una ribonucleasa III $(D C L)$, generando un dúplex de pre-miRNA; este dúplex es transportado del núcleo al citoplasma en donde se une con el complejo Argonauta (AGO) conformando el complejo RISC; finalmente, el complejo se une por complementariedad a los RNAs mensajeros objetivo, induciendo degradación o supresión de la traducción, por que los miRNAs son considerados moléculas silenciadoras de la expresión genética(1).

En plantas, estas moléculas participan en la regulación de diferentes etapas fisiológicas, como el cambio de la fase vegetativa a la floral, en el desarrollo y crecimiento de hojas, tallos, raíces y de órganos reproductivos. También se ha encontrado que los miRNAs regulan la respuesta de las plantas a distintas condiciones de estrés abiótico y biótico como la carencia de nutrientes, salinidad, sequia, estrés oxidativo, frio, radiación UV y por la presencia de virus $(2,3)$. Estudios in silico dirigidos a la ortología de los miRNAs en plantas, han demostrado que los miRNAs son conservados entre especies; sin embargo, también existen miRNAs específicos de especie(4). Los miRNAs maduros en plantas son conservados en mayor grado que los premiRNAs $(2,5)$. La mayoría de los miRNAs que se encuentran conservados en distintas especies regulan genes homólogos(5), esta característica permite analizar y predecir los posibles RNAs mensajeros blancos de miRNAs de especies que no tienen su genoma secuenciado. La predicción de mRNA blanco es indispensable para identificar la función del miRNA, por lo general, esto se realiza bioinformáticamente. El principal criterio usado es la detección de secuencias

\section{INTRODUCTION}

Sequences of miRNAs are single stranded RNA in 18 to 25 nucleotides in length; on plants, their biogenesis starts when miRNAs genes are transcribed by RNA polymerase II, generating primary transcripts with lengths of 200 to 300 nucleotides referred to as pri-miRNAs, which are transcripts containing a short internal stemloop structure near the ribonuclease III (DCL), generating a pre-miRNA duplex. This duplex is transported from the nucleus to the cytoplasm where it joins the complex Argonauta (AGO) forming the RNA-induced silencing complex (RISC); finally, the complex binds to messenger RNAs complementary to the target, inducing degradation or suppression of translation, the miRNAs are considered silencing molecules of gene expression(1).

In plants, these molecules are involved in the regulation of different physiological stages, as the change of the vegetative to the floral development and growth of leaves, stems, roots and reproductive organs. It has also been found that miRNAs regulate plant response to various abiotic and biotic stress such as lack of nutrients, salinity, drought, oxidative stress, cold, UV radiation and the presence of virus $(2,3)$. In silico studies aimed at orthologous plant miRNAs have shown that miRNAs are conserved between species; however, there are also species-specific miRNAs(4). Mature miRNAs in plants are preserved to a greater extent than premiRNAs $(2,5)$. Most miRNAs that are conserved in different species homologous genes regulate(5), this feature allows to analyze and predict potential targets messenger RNAs of miRNAs in species that have its genome sequenced. Predicting target $\mathrm{mRNA}$ is usually essential to identify the role of miRNA, this is done by bioinformatics analysis. The main criterion used is the detection of complementary sequences between the miRNA and its target(6). This is possible because the complementarity between them is perfect or nearly perfect, allowing quick identification and reliable target mRNAs $(2,7)$. 
complementarias entre el miRNA y su blanco(6); esto es posible ya que la complementariedad entre ellos es perfecta o casi perfecta, lo que permite una identificación de mRNAs blanco rápida y confiable(2,7).

Bouteloua gracilis (Willd. ex Kunth) Lag. ex Griffiths es un pasto perenne perteneciente a la familia Poaceae con metabolismo $\mathrm{C}_{4}$, de tallo delgado que crece en bosques, pastizales y matorrales $(8,9)$. Se localiza en las regiones semiáridas de los Estados Unidos y México(10). Esta gramínea es de gran importancia económica, ya que es fuente de forraje para la alimentación de ganado bovino y fauna nativa, por su alto contenido de proteína y alto grado de digestibilidad, además de su capacidad de adaptación a climas adversos como sequía y frío $(11,12)$. Debido a las características anteriores, este pasto ha sido sujeto de diversas investigaciones ecológicas y fisiológicas. Sin embargo, a la fecha no existe información acerca de los miRNAs expresados en $B$. gracilis y por lo tanto, se desconoce su relación con la regulación de la expresión genética en este pasto. En el presente trabajo se aislaron y caracterizaron secuencias de RNAs pequeños a partir de células clorofílicas de Bouteloua gracilis, con el objetivo de identificar miRNAs. Además, se realizó un análisis in silico para la identificación de los potenciales mRNAs blanco de los miRNAs encontrados, así como la búsqueda de los procesos biológicos en los que participan estos genes.

\section{MATERIAL Y MÉTODOS}

Crecimiento de células clorofilicas de B. gracilis La línea celular se desarrolló en INIFAPCelaya(13). Se agregó un inóculo de células clorofílicas de Bouteloua gracilis (H.B.K.) Lag. ex Steud., TIANS 398, a $25 \mathrm{ml}$ de medio MPC líquido, el cual contiene medio basal para plantas Murashige-Skoog, 2,4-D, bencilaminopurina, adenina y sacarosa a pH de 5.8. Los cultivos se mantuvieron en agitación a $90 \mathrm{rpm}$, con luz continua fluorescente $\left(77 \mu \mathrm{mols}^{-1} \mathrm{~m}^{-2}\right)$ a una temperatura de $33 \pm 1{ }^{\circ} \mathrm{C}$ durante cinco días.
Bouteloua gracilis (Willd. Ex Kunth) Lag. ex Griffiths is a perennial grass belonging to the Poaceae family with $\mathrm{C}_{4}$ metabolism are of thin stem that grow in forests, grasslands and thickets $(8,9)$. They are found in semi-arid regions of the United States and Mexico(10). This grass is of great economic importance, because it is a source of fodder for feeding cattle and native wildlife, for its high protein content and high digestibility, and its ability to adapt to adverse weather conditions such as drought and cold $(11,12)$. Due to the above features, this grass has been subject to various ecological and physiological investigations. However, to date there is no information about the miRNAs expressed in $B$. gracilis and therefore its relationship with the regulation of gene expression in this grass is unknown. In this work sequences of small RNAs from cells chlorophyll Bouteloua gracilis were isolated and characterized, with the aim of identifying miRNAs. In addition, an in silico analysis was carried out to identify potential target mRNAs of miRNAs, as well as a search of the biological processes in which these genes involved was performed.

\section{MATERIAL AND METHODS}

Growth of chlorophyll cells of B. gracilis

The cell line was developed in INIFAP-Celaya(13). An inoculum of chlorophyll cells Bouteloua gracilis (HBK) Lag added. ex Steud., TIANSJ98, $25 \mathrm{ml}$ of liquid medium MPC, the basal medium containing Murashige-Skoog plant, 2,4-D, BAP, adenine and sucrose at $\mathrm{pH}$ 5.8. Cultures were maintained under stirring at $90 \mathrm{rpm}$, with continuous fluorescent light $\left(77 \mu \mathrm{mol}^{-1} \mathrm{~m}^{-2}\right)$ at a temperature of $33 \pm 1{ }^{\circ} \mathrm{C}$ for $5 \mathrm{~d}$. Subsequently, cells were harvested by filtration and the excess medium was removed. They were frozen in liquid nitrogen and stored at $-70{ }^{\circ} \mathrm{C}$ until used.

\section{Extraction of total RNA}

Approximately $150 \mathrm{mg}$ of $B$. gracilis cells were lysed by maceration with the Sample Grinding 
Posteriormente, las células se cosecharon por filtración y se eliminó el exceso de medio. Se congelaron en nitrógeno líquido y se almacenaron a $-70{ }^{\circ} \mathrm{C}$ hasta su uso.

\section{Extracción de RNA total}

Aproximadamente $150 \mathrm{mg}$ de células de $B$. gracilis se lisaron por maceración con el sistema "Sample Grinding Kit ${ }^{T M}$ (GE Healthcare, Suecia) y posteriormente, el RNA se aisló con el uso del método de extracción con Trizol ${ }^{\mathrm{TM}}$, (Ambion, EUA) y Plant RNA Isolation Kit ${ }^{\mathrm{TM}}$ (Ambion, EUA) de acuerdo a las especificaciones de los fabricantes.

\section{Clonación de sRNAs}

La clonación de los sRNAs por concatemerización se realizó con el kit miRCat ${ }^{\mathrm{TM}}$ (Integrated DNA Technologies, EUA) de acuerdo a las recomendaciones del fabricante. Los concatámeros obtenidos se clonaron en el vector PCR-TOPO 4 (Invitrogen $^{\mathrm{TM}}$, EUA) para posteriormente introducirlo en bacterias químicamente competentes de $E$. coli One Shot TOP $10^{\mathrm{TM}}$ (Invitrogen, EUA). A partir de las células transformadas, se realizó extracción de DNA plasmídico por minipreparación por lisis alcalina. Las secuencias de sRNAs insertadas en el sitio del polilinker del vector PCR-TOPO 4 se amplificaron con los oligonucleótidos $T 7^{\mathrm{TM}}$ (5'-TAA-TAC-GAC-TCA-CTA-TAG-GG-3') y T3 ${ }^{\text {TM }}$ (5'ATT-AAC-CCT-CAC-TAA-AGG-GA-3') que flanquean los sitios de clonación del vector. El programa de amplificación utilizado fue de desnaturalización inicial $94{ }^{\circ} \mathrm{C}$ por $1 \mathrm{~min}, 35$ ciclos de desnaturalización a $94^{\circ} \mathrm{C}$ por $1 \mathrm{~min}$, alineamiento $55^{\circ} \mathrm{C} 1 \mathrm{~min}$, extensión $72{ }^{\circ} \mathrm{C}$ por $1 \mathrm{~min} y$ al finalizar los ciclos, una extensión final a $72{ }^{\circ} \mathrm{C}$ durante $10 \mathrm{~min}$. Los productos de PCR se separaron en gel de agarosa al $1.5 \%$ y las bandas de 190 a 400 pares de bases (pb) se recuperaron del gel y se purificaron con el uso de minicolumnas Wizard SV Gel and CleanUp System ${ }^{T M}$ de acuerdo a las especificaciones del proveedor. EI DNA amplificado y purificado se envió a la unidad de síntesis y secuenciación
$\mathrm{Kit}^{\mathrm{TM}}$ (GE Healthcare, Sweden) system and subsequently RNA was isolated using the extraction method Trizol ${ }^{\mathrm{TM}}$ (Ambion, USA) and Plant RNA Isolation $\mathrm{Kit}^{\mathrm{TM}}$ (Ambion, USA) according to the manufacturers specifications.

\section{Cloning of sRNAs}

The cloning of the sRNAs by concatemerization was performed with the miRCat ${ }^{\top \mathrm{MM}}$ (Integrated DNA Technologies, USA) kit according to the manufacturer's recommendations. Concatemers obtained were cloned into the PCR 4-TOPO (Invitrogen $^{\mathrm{TM}}, \mathrm{USA}$ ) vector for later insertion into chemically competent bacteria E. coli TOP10 One Shot ${ }^{\mathrm{TM}}$ (Invitrogen, USA). From the transformed cells, by extraction of plasmid DNA by the alkaline lysis miniprep was performed. SRNAs sequences inserted at the site of the polylinker of four PCR-TOPO vector was amplified with $\mathrm{T}^{\text {TM }}$ (5'-TAA-TAC-GAC-TCA-CTA-TAG-GG-3') and $\mathrm{T}^{\mathrm{TM}}$ (5' oligonucleotides -ATT-AAC-CCT-CACTAA-GA-AGG-3') flanking the cloning sites of the vector. The amplification program used a $94{ }^{\circ} \mathrm{C}$ initial denaturation for $1 \mathrm{~min}, 35$ cycles of denaturation at $94^{\circ} \mathrm{C}$ for $1 \mathrm{~min}$, alignment at $55^{\circ} \mathrm{C}$ for $1 \mathrm{~min}$, extension at $72{ }^{\circ} \mathrm{C}$ for 1 min and at the end of the cycles, a final $72{ }^{\circ} \mathrm{C}$ extension for $10 \mathrm{~min}$. The PCR products were separated on agarose gel $1.5 \%$ and the bands 190 to 400 base pair (bp) were recovered from the gel and purified using minicolumns by Wizard SV Gel and Clean-Up System according to fabricant specifications. The purified DNA was amplified and sent for synthesis and DNA sequencing at the Institute of Biotechnology of the UNAM located at Cuernavaca, Morelos, Mexico. Sequencing was performed on a Perkin Elmer Model 3730 (Applied Biosystems, USA).

\section{Bioinformatics analysis}

The obtained sequences were downloaded for FASTA alignment analysis and by using the BLASTn program through NCBI platform (http:/ /blast.ncbi.nlm.nih.gov/Blast.cgi) with the algorithm for alignment two or more sequences, and preset parameters for an alignment of high similarity (MegaBLAST). Sequences corresponding 
de DNA del Instituto de Biotecnología de la UNAM, ubicado en Cuernavaca, Morelos, México. La secuenciación se realizó en un equipo Perkin Elmer modelo 3730 (Applied Biosystems, EUA).

\section{Análisis bioinformático}

Las secuencias obtenidas se descargaron en formato FASTA y mediante análisis de alineamiento utilizando el programa BLASTn, a través de la plataforma del NCBI (http:// blast.ncbi.nlm.nih.gov/Blast.cgi), con el algoritmo de alineamiento de dos o más secuencias, y parámetros preestablecidos para un alineamiento de alta similitud (Megablast). Se eliminaron secuencias correspondientes al vector, así como las de los conectores (5'-ACCTTG-GTG-CCT-ACA-G-3') presentes entre secuencias de los posibles miRNAs.

Las secuencias candidato de 18 a 25 nucleótidos se analizaron en la base de datos miRBase(14), comparándose con los miRNAs maduros del reino Viridiplantae ahí reportados, de acuerdo al algoritmo y parámetros preestablecidos. Las secuencias candidatas también se analizaron en la plataforma UEA Workbench(15) con la herramienta miRCat, para obtener la secuencia precursora, así como su estructura secundaria. Se usaron como referencia los genomas de Oryza sativa, Zea mays, Sorghum bicolor y Glycine max con los parámetros preestablecidos. Además, todas las secuencias se compararon con la base de datos Rfam(16) para buscar posibles anotaciones dentro de los diferentes tipos de RNAs (rRNAs, tRNAs, mRNAs, ncRNAs, etc.) con los parámetros preestablecidos.

Finalmente, a las secuencias que tuvieron similitud con miRNAs conocidos se les realizó la búsqueda de mRNA objetivo con el programa psRNATarget(17). Debido a que el genoma de Bouteloua gracilis no se ha reportado, se utilizó la base de datos de anotación de transcritos de arroz MSU versión 7(18). Los parámetros usados para la búsqueda mRNAs objetivo fueron más restrictivos que los preestablecidos, el "E value" to vector were eliminated, as well as the connector (5'-ACC-TTG-CCT-GTG-ACA G-3') that are present in sequences possible miRNAs.

The candidate sequences of 18 to 25 nucleotids were analyzed in the miRBase(14) database and compared with mature miRNAs Viridiplantae kingdom there reported, according to the algorithm and preset parameters. Candidate sequences were also analyzed in the UEA Workbench(15) with platform miRCat tool for the precursor sequence and secondary structure. They were used as reference genomes of Oryza sativa, Zea mays, Sorghum bicolor and Glycine max with preset parameters. Moreover, all sequences were compared to the Rfam(16) database for possible annotations within the different types of RNAs (rRNAs, tRNAs, mRNAs, ncRNAs, etc.) with preset parameters.

Finally, the sequences similar to known miRNAs in order to find target mRNA was carried out using the psRNATarget(17) program. Because the genome of Bouteloua gracilis has not been reported, the database annotation of transcripts rice MSU version $7(18)$ was used. The parameters used for searching for target mRNAs were more restrictive than the default values, "E value" (maximum expectation) maximum used was 2.0 (3.0 default) and "UPE" value (accessibility to the binding region) up to 20 (25 default); by decreasing the maximum values of both parameters fewer false positives are obtained(17). Sequences of potential target genes were downloaded, and functional analysis of these, with Blast2GO program(19) was performed.

\section{RESULTS}

Identification of miRNAs in Bouteloua gracilis Ten (10) plasmids were amplified, four were selected to generate PCR products ranging from 400 to 150 nucleotides. Sequencing and analysis of the amplified DNA showed the existence of nine sequences with lengths of 18 to 25 nucleotides of the miRNAs characteristic (Table 1). These sequences were analyzed on the basis of data Rfam observed lack of similarity with 
Perla Lucía Ordóñez-Baquera, et al. / Rev Mex Cienc Pecu 2016;7(3):263-274

Cuadro 1. Análisis in silico de las secuencias de sRNAs obtenidas a partir de concatámeros de B. gracilis Table 1. In silico analysis of sRNAs sequences obtained from B. gracilis concatemers

\begin{tabular}{lllll}
\hline No & Sequence 5'-3' & Lg & miRBase & Species \\
\hline 1 & GATCAGATGGAGGCTAAAATC & 21 & miR7828-5p & Ptr \\
2 & AGGGAGCACCCTTCAGTCCAA & 21 & miR319 & Bdi Osa Sbi Zma \\
3 & TTTCATCAACGCTGCACTCAA & 21 & miR397-3p & Mdm \\
4 & ATTGAGTGCAGCGTTGATGAA & 21 & miR397-5p & Lus Bdi \\
5 & ACCAACTAACCTTAGGCA & 18 & $\mathrm{NF}$ & $\mathrm{NA}$ \\
6 & AAACCCCAGTTTCACACCTCCGCT & 24 & $\mathrm{NF}$ & $\mathrm{NA}$ \\
7 & GTACACACATCGATCAGTCTTATT & 24 & $\mathrm{NF}$ & $\mathrm{NA}$ \\
8 & TGTACATCACTAAGGTAACAAAA & 23 & $\mathrm{NF}$ & $\mathrm{NA}$ \\
9 & CAATGACATCGCAAACAAGTGCCT & 24 & $\mathrm{NF}$ & $\mathrm{NA}$ \\
\hline
\end{tabular}

MiRBase database ${ }^{(14)}$ was used to identify mature miRNAs.

$\mathrm{Lg}=$ Length of the sequence; $\mathrm{Ptr}=$ Populus trichocarpa; Bdi= Brachypodium distachyon; Osa= Oryza sativa; Sbi= Sorghum bicolor; Zma= Zea mays; Mdm= Malus domestica; Lus= Linum usitatissimum.

$\mathrm{NF}=$ Not found; NA= Not apply.

(máxima expectación) máximo usado fue 2.0 (3.0 preestablecido) y el valor "UPE" (accesibilidad a la región de unión) como máximo 20 (25 preestablecido); al disminuir los valores máximos de ambos parámetros se obtienen menos falsos positivos(17). Se descargaron las secuencias de los genes objetivo potenciales, y se realizó un análisis funcional de estos, con el programa Blast2GO(19).

\section{RESULTADOS}

\section{Identificación de miRNAs en B. gracilis}

De 10 plásmidos que fueron amplificados, se seleccionaron cuatro que generaron productos de PCR en un rango de 400 a 150 nucleótidos. La secuenciación y análisis del DNA amplificado demostró la existencia de nueve secuencias con longitudes de 18 a 25 nucleótidos característicos de los miRNAs (Cuadro 1). Estas secuencias se analizaron en la base de datos Rfam, observándose la ausencia de similitud con los RNAs ahí reportados (rRNA, tRNA snRNA, snoRNA). El análisis de homología de las secuencias con los miRNAs depositados en miRBase(14), demostró que las secuencias uno reported there RNAs (rRNA, tRNA snRNA, snoRNA). Analysis of sequence homology with the miRNAs deposited in miRBase(14) showed that sequences 1 to 4 had the best alignment with the miRNAs miR7828-5p of Populus trichocarpa(20); the miR319 reported in Brachypodium distachyon(21), Oryza sativa(22), Sorghum bicolor(23) and Zea mays(24); the miR397-3p from Malus(25) and the miR397-5p reported in Linum usitatissimum(26) and Brachypodium distachyon(23). However, five to nine sequences did not show similarity to previously reported miRNAs.

In order to characterize these sequences, the UEA miRCat Workbench tool(15) was used which is a platform for predicting new miRNAs, as well as for performing mapping studies of potential miRNAs in a genome of interest. If the mapping of such genome is positive, it allows for determining whether the miRNA precursor sequence has a stem-loop (pre-miRNAs) secondary structure. The analysis was performed with all the obtained sequences and the results demonstrated that only miRNAs and characterized (miR397 and miR319) generated pre-miRNAs. So the sequence two (miR319) 
a cuatro tuvieron el mejor alineamiento con los miRNAs miR7828-5p de Populus trichocarpa(20); el miR319 reportado en Brachypodium distachyon(21), Oryza sativa(22), Sorghum bicolor(23) y en Zea mays(24); el miR397-3p de was located in the genomes of Zea mays, Oryza sativa and Sorghum bicolor where the structure of the pre-miRNA (Table 2, Figure 1) was obtained. With respect to sequence four (miR397-5p) it was also possible to identify their

Cuadro 2. Análisis in silico de las secuencias de sRNAs obtenidas a partir de concatámeros de B. gracilis, con la plataforma miRCat(15), con los genomas de soya, maíz, sorgo y arroz

Table 2. In silico analysis of sRNAs sequences obtained from concatemers of $B$. gracilis, with miRCat platform (15), with the genomes of soybean, corn, sorghum and rice

\begin{tabular}{lccccccccc}
\hline Spe & Loc & Start & End & St & Sec 5'-3' & Lg & Lg Pre & $\%$ G/C & MFE \\
\hline Zma & chr3 & 210558024 & 210558044 & - & AGGGAGCACCCTTCAGTCCAA & 21 & 170 & 54 & -66.5 \\
Osa & Os01g46984 & 541 & 561 & - & AGGGAGCACCCTTCAGTCCAA & 21 & 192 & 50 & -80.1 \\
Sbi & chro_3 & 1240353 & 1240373 & - & AGGGAGCACCCTTCAGTCCAA & 21 & 200 & 56 & -94.3 \\
Gma & Gm08 & 4639122 & 4639142 & - & ATTGAGTGCAGCGTTGATGAA & 21 & 179 & 39 & -67.3 \\
Gma & Gm13 & 34383089 & 34383109 & - & ATTGAGTGCAGCGTTGATGAA & 21 & 136 & 37 & -56.4 \\
\hline
\end{tabular}

Spe = Species; Loc= location in the genome; Start= Location of start of sequence in the genome; End= Location of end of the sequence in the genome; St= string where sequence is located: Sec 5'-3'= sequence in the $5^{\prime}$ to 3 ' direction; $\mathrm{Lg}=\mathrm{length}$ of the sequence; $\mathrm{Lg}$ Pre= length precursor sequence; \%G/C= percentage of the content of guanine and cytokines in the premiRNA sequence; MFE= minimum free energy of the structure of pre-miRNA; Zma= Zea mays; Osa= Oryza sativa; Sbi= Sorghum bicolor; Gma= Glycine $\max$; Gm08= Cromosome 8; Gm13= Cromosome 13; chro_3= Cromosome 3; Os01g46984= location number of the rice genome sequence.

Figura 1. Estructura secundaria de los pre-miRNAs predichos bioinformáticamente para la secuencia dos (miR319$3 p$ ). En verde, se señala la secuencia del miRNA identificado. A) Localización en el cromosoma uno de Oryza sativa. B) Localización en el cromosoma tres de Sorghum bicolor. C). Localización en el cromosoma tres de Zea mays

Figure 1. Secondary structure bioinformatically predicted of pre-miRNAs for sequence two (miR319-3p). Green indicates the miRNA sequence identified. A) Location of chromosome one of Oryza sativa. B) Location of chromosome three of Sorghum bicolor. C). Location of chromosome three of Zea mays

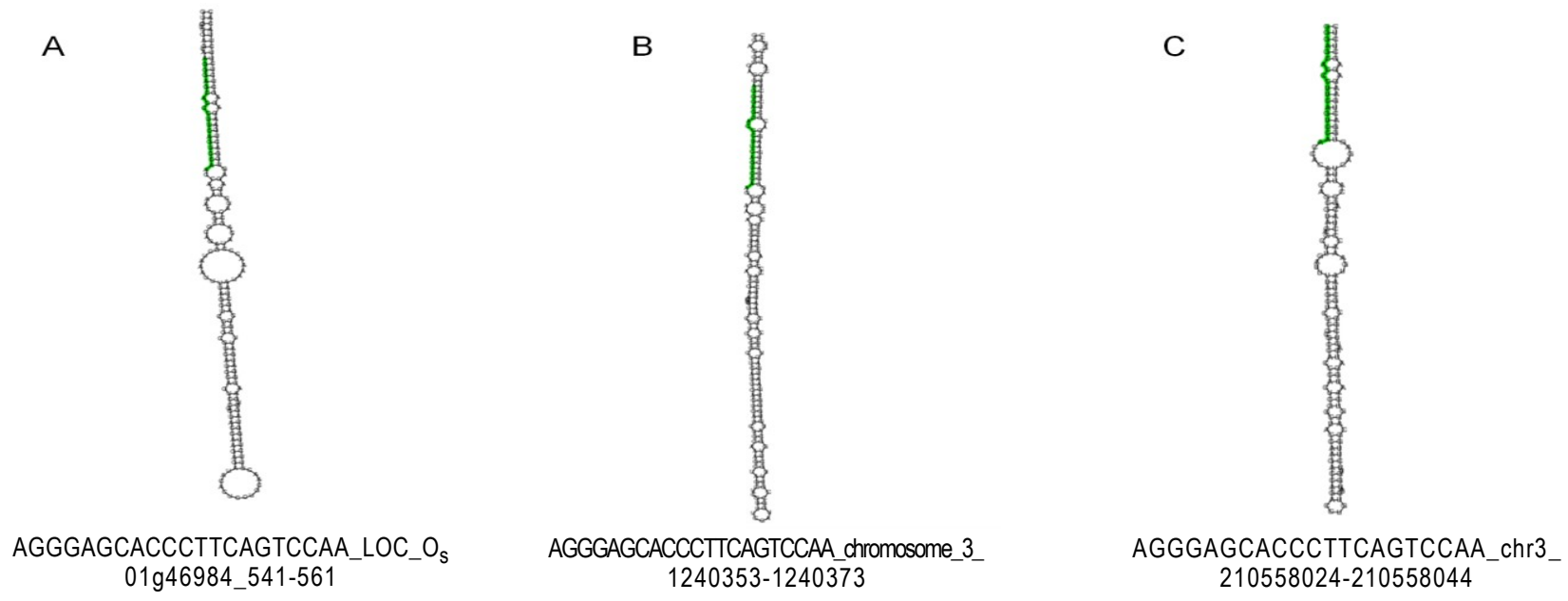


Malus domestica(25) y el miR397-5p reportado en Linum usitatissimum(26) y en Brachypodium distachyon(23) (Cuadro 1). Sin embargo, las secuencias cinco a nueve, no mostraron similitud con miRNAs reportados previamente.

Con el fin de caracterizar estas secuencias, se utilizó la herramienta miRCat de la plataforma UEA Workbench(15) que tiene como función la predicción de miRNAs nuevos, ya que realiza un mapeo de los potenciales miRNAs en estudio a un genoma de interés, y en caso de que el mapeo sea positivo a dicho genoma, determina si el miRNA tiene una secuencia precursora con estructura secundaria tallo-burbuja (premiRNAs). El análisis se realizó con todas las secuencias obtenidas y los resultados demostraron que sólo los miRNAs ya caracterizados (miR397 y miR319) generaron pre-miRNAs. Así la secuencia dos (miR319) se localizó en los genomas de Zea mays, Oryza sativa y Sorghum bicolor donde se obtuvo la estructura de su pre-miRNA (Cuadro 2; Figura 1). Respecto a la secuencia cuatro (miR397-5p) secondary structure, but only in the genome of Glycine max (Table 2; Figure 2). Regarding sequences one, five, six, seven, eight and nine, none could be identified in any of the reference genomes.

\section{MRNA target identification}

Using the psRNATarget(17) program, predicted target mRNAs were used to identify potential targets of all sequences based on the degree of complementarity and the ability to access the complementary region. The analysis showed that only miR397-5p predicted six possible target mRNAs, which encode proteins laccases (Table 3). Functional analysis of target genes showed that encode proteins involved in metabolic processes and catabolic processes of lignin phenylpropanoids. In addition to these functions, each gene has different annotation involved in other processes. Five (Os01g63190, Os01g 63200, Os05g38420, Os11g48060 and Os12g 15680) have copper binding annotation. Two (Os01g63200 and Os12g15680) participate in

Figura 2. Estructura secundaria de los pre-miRNAs predichos bioinformáticamente para la secuencia cuatro (miR397$5 p$ ). En verde se señala la secuencia del miRNA identificado. A) Localización en el cromosoma ocho de Glycine max. B) Localización en el cromosoma 13 de Glycine max

Figure 2. Secondary structure bioinformatically predicted of pre-miRNAs for sequence for four (miR397-5p). In green the miRNA sequence identified is shown. A) Location of chromosome eight of Glycine max. B) Location of chromosome 13 of Glycine max

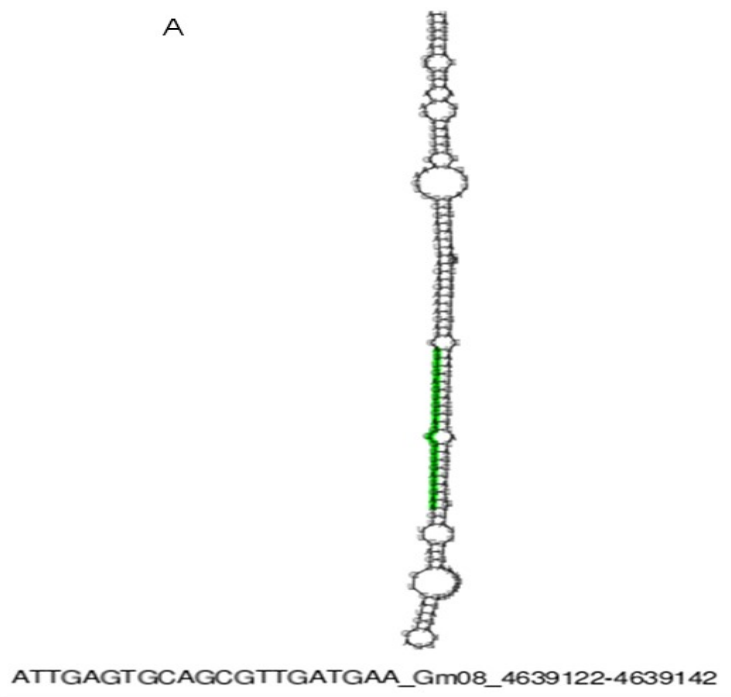

B

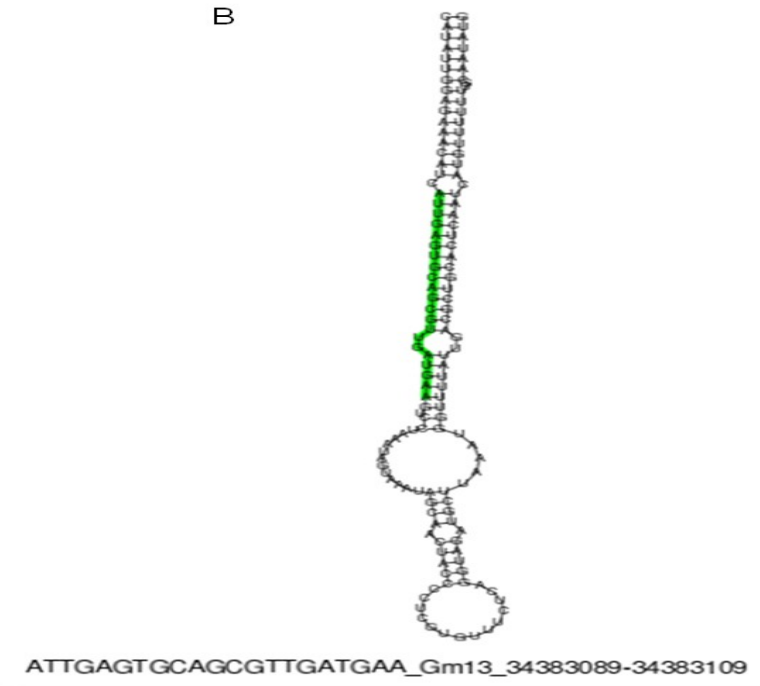


Cuadro 3. mRNAs blanco predichos para la secuencia cuatro (miR397-5p) identificados con el programa psRNATarget(17) Table 3. Predicted target mRNAs for four string (miR397-5p) identified with psRNATarget program(17)

\begin{tabular}{lcccccl}
\hline Name Target & Ev & UPE & Target start & Target end & Target Alignment 5'-3' & Target Description \\
\hline Os05g38420 & 1.0 & 17.7 & 746 & 765 & UCAUCAACGCUGCACUCAAC & Protein Precursor laccase \\
Os12g15680 & 1.5 & 13.1 & 748 & 767 & UCAUCAACGCUGCGCUCAAC & Protein Precursor laccase \\
Os01g63180 & 1.5 & 17.4 & 1087 & 1106 & UCAUCAACGCUGCGCUCAAC & Precursor laccase6 \\
Os01g63200 & 1.5 & 19.7 & 665 & 684 & UCAUCAACGCUGCAGUCAAU & Protein Precursor laccase \\
Os11g48060 & 1.5 & 14.5 & 1179 & 1198 & UCAUCAACGCUGCACUGAAU & Precursor laccase 22 \\
Os01g63190 & 2.0 & 17.5 & 753 & 772 & UCAUCAACGCUGGACUCAAC & Protein Precursor laccase \\
\hline
\end{tabular}

Database annotation of rice transcripts MSU version $7^{(18)}$ was used as reference.

$\mathrm{Ev}=$ Expectation value; UPE= Accessibility to the target value.

también fue posible identificar su estructura secundaria, pero únicamente en el genoma de Glycine max (Cuadro 2; Figura 2). Respecto a las secuencias uno, cinco, seis, siete, ocho y nueve, no fue posible identificarlas en ninguno de los genomas de referencia.

\section{Identificación de RNAm blancos}

Con el uso del programa psRNATarget(17) que predice mRNAs objetivo con base en el grado de complementariedad y en la capacidad de acceso a la región complementaria, se procedió a la identificación de los posibles blancos de todas las secuencias. El análisis demostró que sólo a miR397-5p fue posible predecirle seis mRNAs objetivo, los cuales codifican para proteínas lacasas (Cuadro 3). El análisis funcional de los genes blanco demostró que las proteínas que codifican participan en procesos metabólicos de lignina y procesos catabólicos de fenilpropanoides. Además de estas funciones, cada gen tiene anotación distinta involucrada en otros procesos. Cinco (Os01g63190, Os01g63200, Os05g38420, Os11g48060 y Os12g15680) tienen anotación de unión a Cobre. Dos (Os01g63200 y Os12g15680) participan en el desarrollo del sistema reproductivo. Mientras que Os11g48060 tiene funciones involucradas en la formación de pared celular y Os05g38420 participa durante la respuesta por falta de agua. the development of the reproductive system. While Os11g48060 has functions involved in cell wall formation and Os05g38420 is involved in responses due to lack of water.

\section{DISCUSSION}

Obtaining similar sequences to mature miRNAs reported in miRBase for Bouteloua gracilis indicates that synthesizes these molecules for the regulation of their gene expression. Nine isolated sequences, only four were similar to miRNAs conserved in miRBase; while the remaining five, no records of orthologous sequences in other plant species found. Mapping analysis with miRCat program indicated miRNAs potential, with genomes of other plant species showed clear correlation of miRNAs reported in miRBase and mapping the genomes of the species in which they were identified, and the generation of stable stem-loop secondary structures; however, the rest did not show any selected genome mapping. Together, these results confirm the high degree of conservation of miRNAs, miR319 and miR397 found in grasses such as Zea mays, Oryza sativa and Sorghum bicolor, in addition to the legume Glycine max, as well as in $B$. gracilis. It is interesting that although the number of sequences obtained is low, it was possible to detect the presence of both miR397-5p since it is complementary to 


\section{DISCUSIÓN}

La obtención de secuencias similares a miRNAs maduros reportados en la miRBase indica que Bouteloua gracilis sintetiza estas moléculas para la regulación de su expresión genética. De las nueve secuencias aisladas, sólo cuatro tuvieron similitud con miRNAs conservados en la miRBase; mientras que en las cinco restantes, no se encontraron registros de secuencias ortólogas en otras especies de plantas. El análisis de mapeo con el programa miRCat de nuestros potenciales miRNAs, con genomas de otras especies de plantas demostró clara correlación de los miRNAs reportados en la miRBase y su mapeo en los genomas de las especies en las que fueron identificadas, así como la generación de estructuras secundarias tallo-burbuja estables; sin embargo, el resto no mostró mapeo a ningún genoma seleccionado. En conjunto, estos resultados confirman el alto grado de conservación de los miRNAs, miR319 y miR397 encontrados en gramíneas como Zea mays, Oryza sativa y Sorghum bicolor, además de la leguminosa Glycine max, así como en $B$. gracilis. Es interesante comentar que aunque la cantidad de secuencias obtenidas es baja, fue posible detectar la presencia tanto del miR397-5p, como de su complementario miR397-3p, por lo que es posible que este miRNA tenga participación activa en $B$. gracilis. Con respecto a las secuencias cinco a nueve, la ausencia de ortólogos así como el mapeo negativo a alguno de los genomas de referencia empleados, indica la posibilidad de que estas secuencias sean específicas a $B$. gracilis. Respecto a la secuencia uno, a pesar de que tuvo similitud con el miR7828-5p de Populus trichocarpa, ésta fue muy baja, ya que tuvo cinco incomplementariedades.

Los potenciales mRNAs blanco detectados fueron predichos a partir de la secuencia cuatro (miR397-5p); por tanto, es posible que la expresión de este miRNA regule de manera negativa la expresión de las lacasas, que son enzimas glicoprotéicas que tienen la función de oxidar compuestos fenólicos presentes en la
miR397-3p, so this miRNA might be active in $B$. gracilis. Regarding sequences five to nine, the absence of orthologs and the negative to one of the reference genomes employees mapping indicates the possibility that these sequences are specific to $B$. gracilis. Regarding sequence one, although it was similar with miR7828-5p of Populus trichocarpa, it was very low, since it had five mismatches.

The detected potential target mRNAs were predicted from the sequence four (miR397-5p); therefore, it is possible that the expression of this miRNA negatively regulates expression of laccases, which are glycoprotein enzymes having the function of oxidizing phenolic compounds present in the lignin(27). Inhibition of expression of these enzymes may be due to the fact that, as the chlorophyll cells are undifferentiated, in which there is the presence of lignin, the presence of laccases oxidize to such phenolic compounds are required. On the other hand, in the absence of lignin present, laccases could oxidize other phenolic compounds, which could affect the proper functioning of cells. Further, these genes had also functional annotations involved in the development of the reproductive system, formation of cell wall and response to lack of water, so it is expected that these genes are being muted because it is possible that none of these biological processes occur in undifferentiated cells, from which this study was done. On the other hand, miR319 is a much characterized miRNA, and although it was not possible predict a target in this analysis, it has been reported that one of its main objectives is in TCP transcription factors class II; which participate in the negative regulation of cell growth as reported in Arabidopsis(28).

The fact that other sequences did not present potential targets does not mean they do not exist; the above, it may be due to the fact that the selected parameters for analysis were very high to avoid false positives, or that targets are specific sequences of $B$. gracilis. 
lignina(27). La inhibición de la expresión de estas enzimas puede ser debida al hecho de que, como las células clorofílicas son indiferenciadas, en las que no existe la presencia de lignina, no se requiere la presencia de lacasas para que oxiden a dichos compuestos fenólicos. $O$ bien, al no haber lignina presente, las lacasas pudieran oxidar otro tipo de compuestos fenólicos, lo que podría afectar el buen funcionamiento celular. Además, estos genes también tuvieron anotaciones funcionales involucradas en el desarrollo del sistema reproductivo, en formación de pared celular y respuesta a falta de agua, por lo que también es de esperarse que estos genes estén siendo silenciados, ya que es posible que ninguno de estos procesos biológicos ocurra en las células indiferenciadas, a partir de las cuales se realizó este estudio. Por otro lado, el miR319 es un miRNA muy caracterizado, y aunque no fue posible predecirle algún blanco en este análisis, se ha reportado que tiene como objetivos principales los factores de transcripción TCP clase II; los cuales, participan en la regulación negativa del crecimiento celular reportado en Arabidopsis(28).

El hecho de que el resto de secuencias no presentaran posibles blancos no significa que estos no existan; lo anterior, se puede deber a que los parámetros seleccionados para realizar el análisis fueron muy elevados para evitar al máximo falsos positivos, o que los blancos sean secuencias específicas de $B$. gracilis.

\section{CONCLUSIONES E IMPLICACIONES}

En el presente estudio fue posible identificar cuatro miRNAs reportados en miRBase; dos de ellos, altamente conservados. Estos resultados confirman la presencia de RNAs pequeños como los miRNAs en $B$. gracilis. La identificación del miR397-5p, miR397-3p, así como sus potenciales mRNAs objetivo, que codifican a enzimas con actividad de lacasas, es un indicio de que esta molécula participa muy activamente en estas células. La evaluación de la expresión de este miRNA en diferentes tejidos de la planta, así

\section{CONCLUSIONS AND IMPLICATIONS}

In this study it was possible to identify four miRNAs reported in miRBase; two of them are highly conserved. These results confirm the presence of small RNAs and miRNAs in $B$. gracilis. The identification of miR397-5p, miR397-3p, as well as their potential target mRNAs that encode for enzymes with laccase activity, is an indication that this molecule is very active in these cells. The evaluation of this miRNA expression in different plant tissues and cells and plants grown under conditions of water stress, will reveal the physiological relevance of this miRNA in $B$. gracilis.

\section{ACKNOWLEDGMENTS}

Luz Angelica Muñoz for technical help.

End of english version

como en células y plantas desarrolladas bajo condiciones de estrés hídrico, permitirá conocer la relevancia fisiológica que tiene este miRNA en $B$ gracilis.

\section{AGRADECIMIENTOS}

A la M.C. Luz Angélica Muñoz Bañales, por la ayuda técnica recibida.

\section{LITERATURA CITADA}

1. Mallory $A C$, Vaucheret $H$. Functions of microRNAs and related small RNAs in plants. Nat Genet 2006;38:S31-S36.

2. Jung $\mathrm{JH}$, Seo PJ, Park CM. MicroRNA biogenesis and function in higher plants. Plant Biotechnol Rep 2009;3:111-126.

3. Luan $F$, Han $Y$, Zhu $H$, Shao $Y$, Chen $A$, Tian $H$, Luo $Y$, Zhu B. Computational predicting novel microRNAs in tomato and validating with RT-PCR. Russian J Plant Physiol 2010;57:469479. 
4. Guzman F, Almerao MP, Körbes AP, Loss-Morais G, Margis R. Identification of microRNAs from Eugenia uniflora by high-throughput sequencing and bioinformatics analysis. PLOS ONE 2012;7:e49811.

5. Jones-Rhoades MW. Conservation and divergence in plant microRNAs. Plant Mol Biol 2012;80:3-16.

6. Zeng C, Wang W, Zheng Y, Chen X, Bo W, Song S, Zhang W, Peng M. Conservation and divergence of microRNAs and their functions in Euphorbiaceaous plant. Nucleic Acid Res 2009;38:981-995.

7. Ha M, Pang $M$, Agarwal V, Chen ZJ. Interspecies regulation of microRNAs and their targets. Biochim Biophys Acta 2008;1779:735-742.

8. Evertson J. Bouteloua gracilis. American Nurseryman. 2010. www.amerinursery.com. Acesessed Jun 15, 2014.

9. Valdés-Reyna J, Dávila APD. Clasificación de los géneros de gramíneas (Poaceae) mexicanas. Acta Bot Mexicana 1995;33:37-50.

10. Aguiar $M$, Lauenroth $W$. Local and regional differences in abundance of co-dominant grasses in the shortgrass steppe: a modeling analysis of potential causes. Plant Ecol 2001;156:161-171.

11. Ortiz MV. Fluctuación en el contenido de proteína cruda y fósforo en 3 ecotipos de zacate navajita (Bouteloua gracilis) y banderilla (Bouteloua curtipendula) y 2 ecotipos de zacate toboso (Hilaria mutica) en cuatro estados fenológicos. Contenido y fluctuación de nutrientes de las especies forrajeras consumidas por el ganado en los agostaderos de Chihuahua. Boletín Pastizales RELC-INIP-SARH. 1984;15:120.

12. Morales-Nieto C, Madrid-Pérez L, Melgoza-Castillo A, Martínez-Salvador M, Arévalo-Gallegos S, Rascón-Cruz Q, Jurado-Guerra P. Análisis morfológico de la diversidad del pasto navajita (Bouteloua gracilis Willd ex Kunth) Lag ex Steud. en Chihuahua México. Téc Pecu Méx 2009;47:245256.

13. Aguado-Santacruz GA, Cabrera-Ponce JL, Ramírez-Chávez E, C. León-Ramírez G, Rascón-Cruz Q, Herrera-Estrella L, Olalde-Portugal V. Establishment, characterization and plant regeneration from highly chlorophyllous embryogenic cell cultures of blue grama grass, Bouteloua gracilis (H.B.K) Lag. Ex Steud. Plant Cell Rep 2001;20:131-136.

14. Kozomara A, Griffiths-Jones S. miRBase: integrating microRNA annotation and deep sequencing data. Nucleic Acids Res 2011;39:D152-D157.

15. Stocks MB, Moxon S, Mapleson D, Woolfenden HC, Mohorianu I, Folkes L, Schwach F, Dalmay T, Moulton V. The UEA sRNA workbench: a suite of tools for analysing and visualizing next generation sequencing microRNA and small RNA datasets. Bioinformatics 2012;28:2059-2061.

16. Burge SW, Daub J, Eberhardt R, Tate J, Barquist L, Nawrocki EP, Eddy SR, Gardner PP, Bateman A. Rfam 11.0: 10 years of RNA families. Nucleic Acids Res 2012;41. doi:10.193/ nar/gks1005.

17. Dai X, Zhao PX. psRNATarget: A plant small RNA target analysis server. Nucleic Acids Res 2011;W155-W159.

18. Kawahara $Y$, De-la-Bastide $M$, Hamilton JP, Kanamori $H$, McCombie WR, Ouyang S, Schwartz DC, et al. Improvement of Oryza sativa Nipponbare reference genome using next generation sequence and optical map data. Rice 2013;6:413.

19. Conesa A, Götz S, García-Gómez JM, Talón M, Robles M. Blast2GO: a universal tool for annotation, visualization and analysis in functional genomics research. Bioinformatics 2005;21:3674-3676.

20. Shuai $P$, Liang $D$, Zhang $Z$, Yin $W$, Xia $X$. Identification of drought-responsive and novel Populus trichocarpa microRNAs by high-throughput sequencing and their targets using degradome analysis. BMC Genomics 2013;14:233.

21. Bertolini E, Verelst W, Horner DS, Gianfranceschi L, Piccolo $V$, Inzé $D$, Pé ME, Mica E. Addressing the role of microRNAs in reprogramming leaf growth during drought stress in Brachypodium distachyon. Mol Plant 2013;6:423-443.

22. Jones-Rhoades MW, Bartel DP. Computational identification of plant microRNAs and their targets, including a stressinduced miRNA. Molecular Cell 2004;14:787-799.

23. Dezulian T, Palatnik JF, Huson D, Weigel D. Conservation and divergence of microRNA families in plants. Genome Bio 2005;6:P13. doi:10.1186/gb-2005-6-11-p13.

24. Zhang L, Chia JM, Kumari S, Stein JC, Liu Z, Narechania A, Maher CA, et al. A genome-wide characterization of microRNA genes in maize. PLoS Genet 2009:5(11). doi:10.1371/journal.pgen.1000716.

25. Xia R, Zhu H, An YQ, Beers EP, Liu Z. Apple miRNAs and tasiRNAs with novel regulatory networks. Genome Biology 2012;13:R47. doi:10.1186/gb-2012-13-6-r47.

26. Barvkar VT, Pardeshi VC, Kale SM, Qiu S, Rollins M, Datla $\mathrm{R}$, et al. Genome-wide identification and characterization of microRNA genes and their targets in flax (Linum usitatissimum). Planta 2013;237:1149-1161.

27. Preussler $C A$, Shimizu E, Villalba LL, Zapata PD. Inducción con cobre de la enzima lacasa en el hongo de pudrición blanca Trametes villosa (sw.:Fr.) Kreisel. Rev Cienc Tecnol 2009;12:9-16

28. Nag A, King S, Jack T. miR319a targeting of TCP4 is critical for petal growth and development in Arabidposis. PNAS 2009;106(52)22534-22539. 